\title{
Milk production and reproduction traits of different grades of zebu x Friesian crossbreds under semi-arid conditions
}

\begin{abstract}
Data from Zebu x Friesian crossbred dairy cows of different upgrading kept in the Kenana Sugar Company (KSC) farm, $300 \mathrm{~km}$ south of Khartoum on the bank of the White Nile in the low rainfall savannah region were collected over a period from 1984 to 2004 and analyzed using Harvey's (1990) Least Squares programme.

The results indicated that there were no significant differences in milk yield per lactation, daily milk yield and lactation between the $25 \%$ and $37.5 \%$ genetic groups. The $50 \%$ Zebu x Friesian group produced significantly more milk per lactation $(2721.10 \pm 87.36 \mathrm{~kg})$ compared to the $25 \%$ and $37.5 \%$ groups $(2067.20 \pm 241.62$ and $2192.68 \pm 122.66$, respectively). The milk yield per lactation and daily milk yield of the $50,62.5,75$ and $87.5 \%$ breed groups was not significantly different. There were no significant differences in length of lactation between the $25 \%, 37.5 \%$ and the $50 \%$ group $(267.99 \pm 18.14,273.11 \pm 9.25$ and $278.75 \pm 6.52$, respectively). Groups with $75 \%$ and $87.5 \%$ of Friesian blood proportion had significantly longer lactation days (305.09 \pm 10.63 and 347.07 \pm 30.14 , respectively). The range for dry period was between $78.37 \pm 12.27$ days for the $75 \%$ genetic group to $92.56 \pm 16.76$ days for the $25 \%$ group.

The mean calving intervals for the five genetic groups ranged from $367.85 \pm 21.38$ days for the $75 \%$ group to $394.60 \pm 16.33$ days for the $50 \%$ group. The earliest age at calving (41.56 \pm 2.16 months) was achieved by the $37.5 \%$ group while the latest age at first calving (49.01 \pm 1.29 months) was recorded for the $62.5 \%$ group.

The results of this study and other similar studies in tropical countries provide proof that the local environment (i.e. high temperature, low feed quality and quantity, disease and parasitic loads) can sustain composite genotypes of up to $50 \%$ B. taurus blood and does not lead to significant yield increases in upgraded groups.

The economic feasibility of raising crossbred cows (Zebu x Bos taurus) under the Sudan condition has to be further evaluated in comparison with native dairy breeds to determine the overall efficiency and economic benefits.
\end{abstract}

Key Words: Sudan, cattle, Zebu-Friesian crossbreds, reproduction performance, milk yield

\section{Zusammenfassung}

Titel der Arbeit: Milchproduktion und Reproduktionseigenschaften von Zebu-Friesian-Kreuzungskühen mit unterschiedlichem Kreuzungsgrad unter den Bedingungen der Halbwüste

Leistungsdaten aus dem Zeitraum 1984 - 2004 von Zebu-Friesian-Kreuzungskühen mit unterschiedlichem Kreuzungsgrad der Kenana Sugar Company (KSC) wurden einer Leistungsbewertung unterzogen.

Es konnten keine signifikanten Unterschiede der Laktationsleistung, der täglichen Milchleistung und der Laktationslänge bei Kühen mit einem 25 \% und 37,5 \% Holstein-Friesian-Anteil gefunden werden. Die F1 50 \% Zebu x HF hatten eine signifikant höhere Milchleistung $(2721 \pm 87 \mathrm{~kg})$ im Vergleich zu den genetischen Gruppen $25 \%$ und 37,5 \% mit jeweils $2067 \pm 241$ und $2192 \pm 123 \mathrm{~kg}$. Die Laktationsleistung und die tägliche Milchleistung der genetischen Gruppen $50 \%, 62,5 \%, 75 \%$ und 87,5 \% waren nicht signifikant unterschiedlich. Auch gab es keine signifikanten Unterschiede in der Laktationslänge zwischen den Kreuzungsgruppen mit $25 \%$, $37,5 \%$ und $50 \%$ HF-Anteil (268 $\pm 18 ; 273 \pm 9$ und $279 \pm 6$ ) während die Kreuzungsgruppen mit $75 \%$ und 87,5 $\%$ HF-Anteil eine signifikant längere Laktation aufwiesen (305 \pm 11 und $347 \pm 30)$. Die Trockenperiode schwankte zwischen 78 Tagen für die 75 \% HF-Gruppe und 92 Tagen für die $25 \%$ HF-Gruppe.

Das mittlere Kalbeintervall für die fünf genetischen Gruppen variierte von $368 \pm 21$ Tagen bei der 75 \% HFGruppe bis $395 \pm 16$ Tagen für die $50 \%$-Gruppe. Das niedrigste Abkalbealter wurde mit $42 \pm 2$ Monaten in der 37,5 \% HF-Gruppe und das höchste Abkalbealter mit $49 \pm 1$ Monaten in der 62,5 \% HF-Gruppe gefunden.

Die Ergebnisse dieser Studie sind vergleichbar mit anderen Untersuchungen zur Milchrinderkreuzung in tropischen Ländern und bestätigen, dass natürliche und spezifische lokale Produktionsbedingungen (Temperatur, niedrige Futterqualität, variables Futterangebot, allgemeiner Krankheitsdruck) durch eine Aufkreuzung auf bis zu $50 \%$ zu einer entsprechenden Leistungssteigerung führen, während weiterführende Aufkreuzungen zu keiner nachhaltigen Leistungssteigerung beitragen. Neben einer Leistungsbewertung unterschiedlicher Kreuzungsgrup- 
pen sollte ebenfalls eine ökonomische Bewertung von Kreuzungsprogrammen auch unter Einbeziehung lokaler Milchrinder zur Bewertung der übergeordneten Erzeugungseffizienz umgesetzt werden.

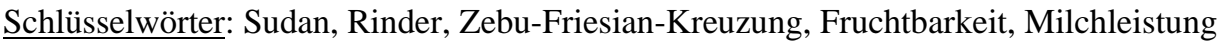

1. Introduction

Crossbreeding with European dairy breeds has been widely used as a method to improve milk production potential in tropical cattle. The first crossbred generation $\left(F_{1}\right)$, derived from indigenous (usually Bos indicus) females mated with exotic (Bos taurus) bulls performed very well in almost all cases. However, further upgrading by repeated backcrossing to the exotic breed gave variable and often disappointing results (SYRSTAD, 1996). REGE (1998) reviewed results of 80 crossbreeding experiments involving European and indigenous breeds in the tropics and estimated high heterotic contributions to milk production traits in the $\mathrm{F}_{1}$ cows, and a significant deterioration in the performance of the $F_{2}$ generations in all traits compared with the $F_{1}$ generation. SYRSTAD (1989) hypothesized that the recombination loss of the co-evolved epistatic parental genes is a contributing factor towards the higher than expected decline in milk production performance of the $\mathrm{F}_{2}$ generations.

In the Sudan, the traditional cattle production sector based on extensive grazing and cattle external feed input does not meet the increasing milk demand of urban areas. Despite the existence of some very promising local dairy breeds (Kenana and Butana) a fast response to increase market oriented milk production was carried out through the importation of special dairy breeds from temperate regions. Currently, milk production around the main urban centres is mainly from crossbred cattle. In fact crossbred cattle now can be found in many remote rural areas and even in the homelands of the improved zebu breeds Kenana and Butana. However, crossbreeding as it is practiced in the Sudan, is haphazard and there is no coherent breeding plan being executed. Many small farmers are opting for continuous upgrading and are purchasing genetic potential that they cannot utilize within the limitations of the local physical and biotic environment. The purpose of this work is to use data from a well managed herd in order to compare the performance of cows with different levels of Bos taurus blood and ascertain the level of foreign blood that is optimum for milk production and reproduction under Sudan conditions. This is an important step towards defining a crossbreeding plan.

\section{Materials and Methods \\ 2.1 Herd location and management}

Crossbred dairy cows used in this study were raised in a farm of 525 hectares of arable land owned by Kenana Sugar Company (KSC) and located 300 km south of Khartoum on the bank of the White Nile in the low rainfall savannah region at $13 \mathrm{~N}$ latitude and 410 meters above sea level. The average rainfall during the study period (1984-2000) was 388.4, relative humidity was 47.3 and the mean annual temperature was $27.8^{\circ} \mathrm{C}$. The maximum recorded temperature during this period was $36.9^{\circ} \mathrm{C}$. There is a clearly defined rainy season with most of the rain falling during the period June to September. The total number of dairy cows in the herd at the time of data collection was 683 together with 713 young stock less than two years old and 101 heifers more than two years old. The foundation herd was formed in 1980 through purchases of crossbred heifers from other farms and the purchase of pure Kenana heifers which were later 
used for crossbreeding with Friesian bulls. Artificial insemination with imported semen was regularly practiced and natural service was resorted to after three failed inseminations. Forages such as Sorghum Bicolor and Clitoria Macrophylla were grown on farm and were fed fresh, as silage or as hay. Three different rations were fed to lactating cows, dry cows and young calves. All three rations were composed of different percentages of ground nut cake, sorghum grains and wheat bran. Roughages and molasses were available to all animals ad-libitum. Animals were housed in three long open sided stables with high roofs (5.5 meters) with no special cooling facilities.

\section{$2.2 \quad$ Data analysis}

Data covering the period from 1984 to 2004 were collected and analyzed using HARVEY's (1990) Least Squares programme. The following fixed model was applied to lactation milk yield, daily milk yield, dry period and calving interval data. Lactation length was analyzed using the same model substituting the linear regression on average daily milk yield for the regression on lactation length. Age at first calving was analyzed using the main basic model but without the effects of parity and the linear regression on lactation length.

$Y_{i j k}=\mu+A_{i}+S_{j}+P_{k}+b D+E_{i j k}$

Where:

$\mathrm{Y}_{\mathrm{ijk}}=$ the $\mathrm{ijk} \mathrm{k}^{\text {th }}$ observation.

$\mu=$ the overall mean.

$A_{i}=$ the $i^{\text {th }}$ year-season of calving (i=1-9).

$S_{j}=$ the $j^{\text {th }}$ random sire effect $(j=1-12)$.

$\mathrm{P}_{\mathrm{k}}=$ effect of $\mathrm{k}^{\text {th }}$ parity number $(\mathrm{k}=1-6)$.

$\mathrm{b}=$ the linear regression of the trait under study on lactation length or daily milk yield.

$\mathrm{D}=$ the deviation of lactation length or daily milk yield from the overall mean

$\mathrm{E}_{\mathrm{ijk}}=$ the residual error.

Table 1

Analysis of variance of lactation and daily milk yield, lactation length and dry period (Varianzanalyse zur Laktations- und täglichen Milchleistung, Laktationslänge und Trockenperiode)

\begin{tabular}{lcccccc}
\hline Source & DF & $\begin{array}{c}\text { Milk yield per } \\
\text { lactation (MS) }\end{array}$ & $\begin{array}{c}\text { Daily milk } \\
\text { yield (MS) }\end{array}$ & $\begin{array}{c}\text { Lactation } \\
\text { length (MS) }\end{array}$ & DF & $\begin{array}{c}\text { Dry period } \\
\text { (MS) }\end{array}$ \\
\hline Genetic group & 5 & $5957639.34^{* *}$ & $63.57^{* *}$ & $12591.05^{* *}$ & 4 & $1093.58^{\text {ns }}$ \\
Year-season of & 7 & $4171934.72^{* *}$ & $43.90^{* *}$ & $4353.28^{\text {ns }}$ & 6 & $3454.90^{\text {ns }}$ \\
calving & 5 & $24120640.50^{* *}$ & $310.85^{* *}$ & $25649.88^{* *}$ & 5 & $6667.39^{*}$ \\
$\begin{array}{l}\text { Parity } \\
\text { Linear regression }\end{array}$ & 1 & $350500340.61^{* *}$ & $232.48^{* *}$ & $111129.50^{* *}$ & 1 & $174513.00^{* *}$ \\
on lactation length & 748 & 781575.51 & 9.11 & 4356.07 & 632 & 3137.13 \\
Remainder & D.F $=$ Degrees of freedom ${ }^{*}=\mathrm{p}^{*}<0.05$ & $* *=\mathrm{p}^{*}<0.001$ & n.s $=$ not significant & &
\end{tabular}

3. Results

Results of the analysis of variance performed on the KSC herd data using a fixed model are compiled in Table 1 . The effects of genetic group, parity and the linear regression on lactation and daily milk yield and lactation length were all highly significant $(\mathrm{p}<0.01)$. The effects of year-seasons of calving on lactation and daily milk yield were highly significant $(p<0.01)$ but their effects on lactation length were not 
significant. Dry period was affected significantly $(\mathrm{p}<0.05)$ by parity and highly significantly $(\mathrm{p}<0.01)$ by the linear regression on lactation length.

Table 2

Least squares means and standard errors of milk yield per lactation, daily milk yield (kg), lactation length (days) and dry period (days) of the KSC herd (Milchleistung pro Laktation und tägliche Milchleistung in kg, Laktationslänge in Tagen und Trockenperiode in Tagen der Kreuzungsmilchkühe)

\begin{tabular}{|c|c|c|c|c|c|c|}
\hline \multirow[t]{2}{*}{ Item } & No & Milk yield & $\begin{array}{l}\text { Daily milk } \\
\text { yield }\end{array}$ & $\begin{array}{l}\text { Lactation } \\
\text { length }\end{array}$ & No & Dry period \\
\hline & & $\mathrm{LSM} \pm \mathrm{SE}$ & $\mathrm{LSM} \pm \mathrm{SE}$ & $\mathrm{LSM} \pm \mathrm{SE}$ & & $\mathrm{LSM} \pm \mathrm{SE}$ \\
\hline Overall mean & 767 & $2599.57 \pm 110.91$ & $8.96 \pm 0.37$ & $292.64 \pm 08.28$ & 649 & $84.20 \pm 8.50$ \\
\hline Genetic groups $25 \%$ & 85 & $2067.20 \pm 241.62^{\mathrm{a}}$ & $7.21 \pm 0.83^{\mathrm{a}}$ & $267.99 \pm 18.14^{\mathrm{a}}$ & 62 & $92.56 \pm 16.76$ \\
\hline $37.5 \%$ & 110 & $2192.68 \pm 122.66^{\mathrm{a}}$ & $7.99 \pm .42^{\mathrm{a}}$ & $273.11 \pm 9.25^{\mathrm{a}}$ & 182 & $79.17 \pm 10.97$ \\
\hline $50 \%$ & 228 & $2721.10 \pm 87.36^{\mathbf{b}}$ & $9.77 \pm 0.30^{\mathbf{b}}$ & $278.75 \pm 6.52^{\mathrm{a}}$ & 212 & $86.61 \pm 9.37$ \\
\hline $62.5 \%$ & 182 & $2686.27 \pm 101.14^{\mathbf{b}}$ & $9.57 \pm 0.35^{\mathbf{b}}$ & $283.82 \pm 07.55^{\mathbf{b}}$ & 140 & $83.71 \pm 10.05$ \\
\hline $75 \%$ & 97 & $2955.54 \pm 142.83^{\mathbf{b}}$ & $10.17 \pm 0.49^{\mathbf{b}}$ & $305.09 \pm 10.63^{\mathbf{c}}$ & 53 & $78.37 \pm 12.27$ \\
\hline $87.5 \%$ & 65 & $2973.74 \pm 405.12^{\mathbf{b}}$ & $9.09 \pm 1.38^{\mathrm{ab}}$ & $347.07 \pm 30.14^{\mathrm{d}}$ & - & (1) \\
\hline Parities First & 232 & $1829.75 \pm 124.48^{\mathrm{a}}$ & $6.18 \pm 0.43^{\mathrm{a}}$ & $321.79 \pm 09.59^{\mathrm{a}}$ & 173 & $103.01 \pm 10.69^{\mathrm{a}}$ \\
\hline & 178 & $2332.01 \pm 131.92^{\mathbf{b}}$ & $8.04 \pm 0.45^{\mathbf{b}}$ & $289.33 \pm 09.93^{\mathbf{b}}$ & 151 & $86.12 \pm 10.63^{\mathbf{b}}$ \\
\hline $\begin{array}{l}\text { Second } \\
\text { Third }\end{array}$ & 152 & $2700.50 \pm 141.35^{c}$ & $9.40 \pm 0.48^{\mathrm{c}}$ & $293.83 \pm 10.54^{\mathbf{b}}$ & 122 & $76.70 \pm 11.53^{\mathbf{b}}$ \\
\hline Fourth & 103 & $2772.11 \pm 145.83^{\mathrm{c}}$ & $9.65 \pm 0.50^{c}$ & $288.41 \pm 10.88^{\mathbf{b}}$ & 83 & $77.11 \pm 11.93^{\mathrm{b}}$ \\
\hline Fifth & 60 & $2994.65 \pm 147.10^{c}$ & $10.24 \pm 0.50^{\mathrm{c}}$ & $281.04 \pm 10.10^{\mathbf{b}}$ & 61 & $77.37 \pm 12.47^{\mathbf{b}}$ \\
\hline Sixth & 42 & $2968.42 \pm 130.43^{\mathrm{c}}$ & $10.29 \pm 0.45^{\mathrm{c}}$ & $281.42 \pm 9.076^{\mathbf{b}}$ & 59 & $84.20 \pm 11.38^{\mathrm{b}}$ \\
\hline \multicolumn{7}{|l|}{ Calving year - season } \\
\hline 1984-1990 Winter & 67 & $2462.16 \pm 327.57$ & $8.42 \pm 1.12$ & $283.35 \pm 24.47$ & 42 & $92.10 \pm 57.00$ \\
\hline Wet summer & 78 & $2004.53 \pm 519.74$ & $7.42 \pm 1.78$ & $326.76 \pm 38.80$ & - & - \\
\hline 1991-1997 Winter & 92 & $2578.36 \pm 109.18$ & $8.90 \pm 0.37$ & $279.66 \pm 8.17$ & 87 & $77.38 \pm 7.47$ \\
\hline \multirow{2}{*}{$\begin{array}{l}\text { Dry summer } \\
\text { Wet summer }\end{array}$} & 106 & $2436.78 \pm 119.56$ & $8.41 \pm 0.41$ & $285.10 \pm 8.98$ & 94 & $70.28 \pm 8.31$ \\
\hline & & $2737.23 \pm 118.61$ & $9.57 \pm 0.41$ & $289.28 \pm 8.85$ & 72 & $77.81 \pm 8.78$ \\
\hline 1998-2004 Winter & 136 & $2729.77 \pm 107.83$ & $9.19 \pm 0.37$ & $299.89 \pm 8.02$ & 143 & $96.40 \pm 7.79$ \\
\hline & 122 & $2717.76 \pm 113.19$ & $9.19 \pm 0.39$ & $288.23 \pm 8.45$ & 108 & $88.35 \pm 8.90$ \\
\hline \multirow{2}{*}{$\begin{array}{l}\text { Wet summer } \\
\text { Linear regression on } \\
\text { lactation length }\end{array}$} & 166 & $3129.10 \pm 111.44$ & $10.63 \pm 0.38$ & $288.83 \pm 8.36$ & 103 & $85.37 \pm 8.09$ \\
\hline & & $10.69 \pm 0.51$ & $0.01 \pm 0.00$ & - & & $-0.37 \pm 0.05$ \\
\hline $\begin{array}{l}\text { Linear regression on } \\
\text { daily milk yield }\end{array}$ & & - & 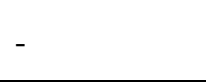 & $4.16 \pm 0.82$ & & - \\
\hline
\end{tabular}

LSM = Least squares means $\quad$ SE = Standard error

Within classes of fixed effects LSMs not carrying the same superscripts are significantly different $(\mathrm{P}<0.05)$

There were no significant differences in milk yield per lactation and daily milk yield (Table 2) between the $25 \%$ and $37.5 \%$ genetic groups (2067.20 $\pm 241.62,7.21 \pm 0.83 \mathrm{~kg}$. and $2192.68 \pm 122.66,7.99 \pm 0.42 \mathrm{~kg}$, respectively). Differences between the two groups in lactation length were also small and insignificant. However, compared to these two groups the $50 \%$ group produced significantly more milk per lactation and daily milk yield (2721.10 \pm 87.36 and $9.77 \pm 0.30 \mathrm{~kg}$, respectively). The milk yield per lactation of the $50,62.5,75$ and $87.5 \%$ breed groups was not significantly different. The same was true with regard to daily milk yield. There were no significant differences in length of lactation between the $25 \%, 37.5 \%$ and the 50\% group (267.99 $\pm 18.14273 .11 \pm 9.25$ and $278.75 \pm 6.52$, respectively). However, the 75 and $87.5 \%$ groups had significantly longer lactations (305.09 \pm 10.63 and $347.07 \pm 30.14$, respectively). The range for dry period was between $78.37 \pm 12.27$ days for the $75 \%$ genetic group to $92.56 \pm 16.76$ days for the $25 \%$ group.

There were significant and increasing differences between parities in milk yield per lactation and daily milk yield (Table 2). Lactation length showed a reverse trend with the longest lactation achieved after the first parity (321.79 \pm 9.59$)$ and the shortest after the fifth parity (281.04 \pm 10.10$)$. Dry periods became shorter with the progress of 
parities. It was $103.01 \pm 10.69$ in the first parity and decreased to below 90 days in the later parities. There were significant differences between year-seasons of calving in lactation and daily milk yield and in lactation length but no consistent trend could be detected.

The analysis of variance presented in Table 3 shows that the effects of genetic group on calving interval were not significant. In the present study, the effect of genetic group on age at first calving was highly significant. Year seasons of cow birth had highly significant effects on age at first calving but year season of calving had no significant effect on calving interval. The linear regression of calving interval on lactation length was highly significant.

Table 3

Analysis of variance of calving interval and age at first calving (Varianzanalyse für Abkalbeintervall und Alter der Erstkalbung)

\begin{tabular}{|c|c|c|c|c|}
\hline Source & D.F & $\begin{array}{c}\text { Calving interval } \\
\text { MS }\end{array}$ & D.F. & $\begin{array}{c}\text { Age at first calving } \\
\text { MS }\end{array}$ \\
\hline Genetic group & 4 & $6633.45^{\mathrm{ns}}$ & 5 & $433912.61^{* *}$ \\
\hline Year-season & 6 & $12422.21^{\mathrm{ns}}$ & 8 & $449330.36 * *$ \\
\hline Parity & 5 & $28953.46 * *$ & - & \\
\hline Linear regression on lactation length & 1 & $90334.24 * *$ & - & - \\
\hline Remainder & 632 & 9534.36 & 653 & 85975.96 \\
\hline
\end{tabular}

Table 4

Least squares means and standard errors of calving interval (days) and age at first calving (months) (Abkalbeintervall in Tagen und Alter bei Erstkalbung in Monaten der Kreuzungskühe)

\begin{tabular}{|c|c|c|c|c|c|}
\hline \multirow[t]{2}{*}{ Items } & & No. & Calving interval & No. & $\begin{array}{l}\text { Age at first } \\
\text { calving }\end{array}$ \\
\hline & & \multicolumn{2}{|r|}{$\mathrm{LSM} \pm \mathrm{SE}$} & \multicolumn{2}{|r|}{$\mathrm{LSM} \pm \mathrm{SE}$} \\
\hline Overall mean & & 649 & $386.03 \pm 14.84$ & 667 & $46.00 \pm 3.78$ \\
\hline \multirow[t]{5}{*}{ Genetic groups } & $25 \%$ & 62 & $386.48 \pm 29.22$ & 59 & $43.79 \pm 4.56^{\mathrm{ab}}$ \\
\hline & $37.5 \%$ & 182 & $379.87 \pm 19.12$ & 194 & $41.56 \pm 2.16^{\mathbf{b}}$ \\
\hline & $50 \%$ & 212 & $394.60 \pm 16.33$ & 216 & $43.74 \pm 1.40^{\mathrm{ab}}$ \\
\hline & $62.5 \%$ & 140 & $382.40 \pm 17.52$ & 141 & $49.01 \pm 1.29^{c}$ \\
\hline & $75 \%$ & 53 & $367.85 \pm 21.38$ & 57 & $47.64 \pm 1.82^{\mathrm{abc}}$ \\
\hline \multirow[t]{6}{*}{ Parities } & $1^{\mathrm{st}}$ & 173 & $423.08 \pm 18.63^{a}$ & & \\
\hline & $2^{\text {nd }}$ & 151 & $376.63 \pm 18.53^{\mathbf{b}}$ & & \\
\hline & $3^{\text {rd }}$ & 122 & $374.02 \pm 20.11^{\mathbf{b}}$ & & \\
\hline & $4^{\text {th }}$ & 83 & $372.78 \pm 20.79^{\mathbf{b}}$ & & \\
\hline & $5^{\text {th }}$ & 61 & $379.17 \pm 21.74^{\mathbf{b}}$ & & \\
\hline & $6^{\text {th }}$ & 59 & $367.75 \pm 19.83^{b}$ & & \\
\hline \multicolumn{6}{|l|}{ year - seasons } \\
\hline \multirow[t]{3}{*}{ 1984-1990 } & Winter & 78 & $388.53 \pm 99.38$ & 74 & $49.22 \pm 1.64$ \\
\hline & Dry Summer & & - & 59 & $51.41 \pm 2.94$ \\
\hline & Wet Summer & & - & 53 & $51.86 \pm 3.22$ \\
\hline \multirow[t]{3}{*}{ 1991-1997 } & Winter & 75 & $370.08 \pm 13.02$ & 86 & $41.39 \pm 1.23$ \\
\hline & Dry summer & 81 & $383.42 \pm 14.49$ & 58 & $40.56 \pm 5.03$ \\
\hline & Wet summer & 82 & $376.22 \pm 15.31$ & 37 & $50.43 \pm 7.04$ \\
\hline \multirow[t]{3}{*}{$1998-2004$} & Winter & 134 & $406.22 \pm 13.57$ & 109 & $40.92 \pm 1.51$ \\
\hline & Dry summer & 93 & $389.75 \pm 15.51$ & 97 & $40.15 \pm 3.06$ \\
\hline & Wet summer & 106 & $361.46 \pm 14.11$ & 92 & $39.63 \pm 3.48$ \\
\hline $\begin{array}{l}\text { Linear regression on } \\
\text { lactation length }\end{array}$ & & & $0.27 \pm 0.090$ & & \\
\hline
\end{tabular}

The mean calving intervals for the five genetic groups ranged from $367.85 \pm 21.38$ days for the $75 \%$ group to $394.60 \pm 16.33$ days for the $50 \%$ group (Table 4 ). The earliest age 
at calving (41.56 \pm 2.16 months) was achieved by the $37.5 \%$ group while the latest age at first calving (49.01 \pm 1.29 months) was recorded for the $62.5 \%$ group. Calving interval in the different parities ranged from $367.75 \pm 19.83$ days in the sixth parity to a high of $423.08 \pm 18.63$ days in the first parity. In the first year- season group, age at first calving was high and ranged from $49.22 \pm 1.64$ months in winter to $51.86 \pm 3.22$ months in wet summer and the lowest ages at first calving (39.63 \pm 3.48 months) were obtained in the wet summer of the last year-season group (1998-2004).

\section{$4 . \quad$ Discussion}

4.1 Milk production traits

The present study indicates that going beyond 50\% Bos taurus inheritance does not significantly improve milk yield per lactation or daily milk yield. Both lactation and daily milk yield increased significantly with the rise in Bos taurus blood up to 50\% (2721.10 \pm 87.36 and $9.77 \mathrm{~b} \pm 0.30$, respectively) and then there was no significant change as foreign blood rose to $87.5 \%$. Mounting evidence from the Sudan and other tropical countries (SYRSTAD, 1989; MADALENA et al., 1990; SYRSTAD, 1996; MADALENA, 1998; REGE, 1998) indicates that 50\% is probably the optimum level of Friesian blood with regard to the amount of milk produced. SYRSTAD (1989) found that there was no significant difference in milk yield between $F_{1}$ crosses of $B$. taurus and $B$. indicus and $75 \%$ backcrosses to $B$. taurus. In an analysis involving 80 data sets REGE (1998) reported similar findings. He stated that the milk yield per lactation of $F_{1}$ crosses between $B$. taurus and $B$. indicus was $2195+30.1$ and the average lactation length was $309+3.6$. He indicated that grades higher than $50 \%$ did not perform better than the $\mathrm{F}_{1}$.

OSMAN and RUSSEL (1974) analysed performance records of different grades of $B$. Taurus x Zebu cattle from Ghurashi Dairy in Khartoum North and found that lifetime milk yield increased with increase of $B$. taurus blood up to $75 \%$ but because of infertility problems and high mortality rates they concluded that 50\% European blood was probably the most suitable level for Sudan conditions. FADEL-MOULA (1994) in his study of production performance data of different grades of Friesian $\mathrm{x}$ Butana or Kenana at the University of Khartoum Farm reported that cows with 50\% foreign blood exhibited the highest milk yield per lactation and daily milk yield (2729.85 \pm 1014 and $7.94 \pm 2.40 \mathrm{~kg}$, respectively).

Also in the Sudan ALI et al. (1988) analyzed data from the Gezira university farm and reported that first lactation milk yield of crossbred (Friesian x Kenana or Butana) cows having 50\%(109 cows), 62.5\%(14 cows) and 75\%(10 cows) Friesian blood was 1953.17, 2548 and $1876.06 \mathrm{~kg}$, respectively. AGEEB and HILLER (1991) found in their study on Friesian x Kenana and Friesian x Butana crossbreds that the production in the first parity increased with increased age at first calving from $1504 \mathrm{~kg}$ for animals calving at less than 3 years of age to $2107 \mathrm{~kg}$ for those calving at more than 4 years.

GOSHU (2005) reported that lifetime milk yield of $F_{1}, 3 / 4,7 / 8$ and 15/16 Friesian $x$ Boran crosses was $14342 \pm 127,12074 \pm 90,7891 \pm 117$ and $7343 \pm 206$. The author concluded that Friesian blood levels in Ethiopian dairy cattle should be stabilized at a maximum of 75\%. WOLLNY et al. (1998) reported that the average milk yield of Malawi zebu x Friesian crosses in small holder farms $(n=38)$ was $1163 \pm 999$ kg per 
cow per year. The high standard deviation (999) might have been due to the small data size and other systematic effects.

In contrast, improved Butana and Kenana cattle breeds under average management of government stations produced relatively high milk yield. MUSA et al. (2005) estimated a mean lactation milk yield of $1662.57 \pm 108.89 \mathrm{~kg}$ for the Butana herd in Atbara Livestock Research Station, while EL-HABEEB (1991) obtained a mean lactation milk yield of $1423.58+551.7 \mathrm{~kg}$ for the Kenana herd in Um-Benein Livestock Research Station.

It appears safe to conclude that 50\% crossbreds in Sudan excel average local improved types by about 800 to1000 kg milk per lactation. However, crossbred's costs of feeding, housing and veterinary care probably exceed those of local types. In addition fertility problems and high mortality rates among high grade crossbred cattle have been indicated (OSMAN and RUSSEL, 1974). On the other hand it is clear that screening the local populations can result in herds with equivalent performance to the crossbreds.

Lactation length appeared to increase significantly with the rise in Friesian blood beyond the $50 \%$ level reaching $283.82 \pm 7.55$, 305.09 \pm 10.63 and $347.07 \pm 30.14$ for cows with $62.5,75$ and $87.5 \%$ Friesian inheritance, respectively. However, the number of animals in the latter group was small and the results have a rather large standard error. ISHAG (2000) reported an average lactation length of 291.34+2.12 days for 300 crossbred Friesian $\mathrm{x}$ Kenana cows kept at KSC with no significant $(\mathrm{p}>0.05)$ differences between crossbreds in different upgrading stages. ALI et al. (1988) found that the lactation length of 50, 62.5, 75\% Friesian x Kenana or Butana crossbreds was 306, 369 and 298 days. REGE (1998) stated that the average lactation length of $F_{1}$ crosses between $B$. taurus and B. indicus was 309+3.6 days.

It appears that most of the variation in the dry period was environmental in nature with a similar effect on different crossbred groups. FADEL-MOULA (1994) estimated an overall mean of dry period for different grades of Friesian x Kenana or Butana as $96 \pm 60$ days. AGYEMANG and NKHONJERA (1986) in Malawi found that the overall mean dry period of Friesian crossbreds in small holder farms was $128 \pm 120$ days with 116 days for 50\% Friesian and 98 days for $75 \%$ Friesian inheritance. They also revealed that the crossbred group, lactation number, year, month of calving and interaction between crossbred group and month of calving had no significant ( $p>0.05$ ) effect on the trait.

\subsection{Reproduction traits}

Reproductive performance of crossbred $B$. taurus x zebu bears special significance since it is one of the two main areas next to milk yield in which temperate breeds are expected to complement local zebu cattle. Based on the evidence obtained from this study it appears that calving interval was not affected by the percentage of exotic blood. DEMEKE et al. (2004) analyzed records of 1496 cows of Boran and Boran crossbreds with different levels of Friesian or Jersey blood. They found no significant crossbred group effect on calving interval, open days and number of services per conception but a significant effect on age at first calving. In the present study estimates of calving interval ranged between $394.60 \pm 16.33$ days for the $50 \%$ group and $367.85+21.38$ days for the $75 \%$ group. HAILE-MARIAM et al. (1993) in Ethiopia found that the mean calving intervals were 465, 552, 525 and 487 days for Boran cows 
naturally mated to Boran and Friesian bulls, Boran and $\mathrm{F}_{1}$ cows artificially inseminated with Friesian semen, respectively. Most reports in the literature indicate that calving interval increases with the rise in $B$. taurus blood beyond $50 \%$. In Brazil TEODORO and MADALENA (2003) studied different crossbred grades of Holstein, Jersey, or Brown Swiss sires with Holstein-Friesian/Gir dams. They found that Holstein crosses were generally superior to other crosses in production traits while Jersey crosses performed better in reproduction. Calving intervals of 75, 81.25 and

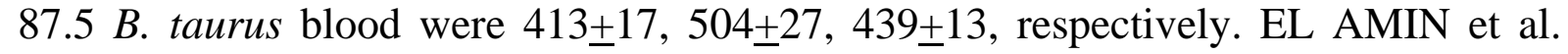
(1986) studied four crossbred groups of $0-25 \%, 26-49,50 \%$ and $51-71 \%$ Holstein blood. The overall mean calving interval was estimated at 441 days based on 4004 records and the calving interval of 50\% crossbred estimated from 1689 records was shorter by 25 days.

Age at first calving was significantly $(\mathrm{p}<0.01)$ affected by the percentage of exotic blood which indicates the presence of differences in the rates of maturity of the different crossbred groups. A similar result was found by ALI et al. (1988) who reported that age at first calving of 50\% $(n=109), 62.5 \%(n=14)$ and $75 \%(n=10)$ zebu $x$ Friesian crossbreds was 42, 36 and 50 months, respectively. In Brazil FACO et al. (2005) found that the earliest age at first calving $(n=652)$ and the shortest calving interval $(n=1865)$ among five Holstein $x$ Gir genetic groups were those of the $50 \%$ group (33.41 \pm 0.21 months, and $409.14 \pm 4.20$ days, respectively). The highest estimate of age at first calving ( $n=396)$ was that of the $62.5 \%$ group (35.12 \pm 0.29 months). Calving interval was highest in the 62.5\% $(n=234)$ and the $75 \%(n=1286)$ groups (418.09 \pm 7.06 and $418.60 \pm 4.58$ days, respectively)

McDOWELL (1985) compared local types with crosses of five European breeds. He found that crosses excelled local types in age at first calving, milk yield, days in milk, and calving interval. However, he concluded that performance is highly dependant on feeding quality, e.g. on tropical grasses and crop residues and the best sustained milk yield was 1800 to $2200 \mathrm{~kg}$ of milk per lactation.

It appears from the weight of evidence presented in this study and other similar studies in tropical countries that the local environment (i.e. high temperature, low feed quality and quantity, disease and parasitic loads challenge) can sustain composite genotypes of up to $50 \%$ B. taurus blood. Many studies have indicated the superiority of $\mathrm{F}_{1}$ crosses over higher grades of both production and reproduction traits in low input production systems prevalent in the tropics (SYRSTAD, 1989; MADALENA et al., 1990; SYRSTAD, 1996; MADALENA, 1998; REGE, 1998; WOLLNY, 1998). This should entail changes in the present chaotic practice of applying AI with semen from dairy breeds. CHAGUNDA et al. (1998) evaluated the AI program for small scale dairy farms in Malawi. They showed that AI program applies a breed substitution policy resulting in an increase of high grade Holstein Friesian x Malawi zebu crosses (>7/8 Friesian) and a decrease of the Malawi zebu, 1/2 and 3/4 Friesian populations during the study period (from 1985 to 1994). Breeding goals need to be defined in such a way as to maximize the utilization of $50 \%$ crosses, probably in the form of a synthetic population. Evidence indicates that some heterotic effect will be lost as a result of such policy (REGE, 1998; VACCARO et al., 1999) and recombination losses may appear in inter se mating. Crossbreeding between $F_{1}$ and $3 / 4$ crossbreds may however be a satisfactory option for improving the market oriented dairy production. 
However, no attempt has yet been made to study the economics of raising crossbred compared to local cattle under Sudan conditions. This is important since many reports indicate that improved local types such as Kenana and Butana are capable of producing more than $1500 \mathrm{~kg}$ of milk per lactation under average management of government stations.

\section{References}

AGEEB, A.G.; HILLERS, J.K.:

Effect of crossing local Sudanese cattle with British Friesian Bull. Trop. Anim. Health. Prod. Afr. 39 (1991), 69-76

AGYEMANG, K.; NKHONJERA, L. P.:

Evaluation of the productivity of crossbred dairy cattle on smallholder and government farms in the Republic of Malawi. (1986) ILCA Research Report 12. ILCA (International Livestock Centre for Africa), Addis Ababa, Ethiopia. 39 pp.

ALI, T.E.; AHMED, F.A.; OMBABI. Y.A.:

Productivity of crossbred zebu cattle with different levels of Friesian blood. Sudan J. Anim. Prod. 1 (1988) 2, 69-78

CHAGUNDA, M.C.; WOLLNY, C.B.A.; BRUNS, E.; KAMWANJA, L.A.:

Evaluation of artificial insemination program for small scale dairy farms in Malawi. Arch. Tierz., Dummerstorf 41 (1) (1998), 45 - 51

DEMEKE, S.; NESER F. W. C.; SCHOEMAN S. J.:

Estimates of genetic parameters for Boran, Friesian and crosses of Friesian and Jersey with the Boran cattle in the tropical highlands of Ethiopia: reproduction traits. J. Anim. Breed. Genet. 121 (2004) 1, 57

EL-HABEEB, E.A.:

Variation in reproductive and milk production traits in Butana and Kenana dairy cattle in the Sudan. (1991) M.V.Sc Thesis, University of Khartoum, Sudan

FADEL-MOULA, A.E:

Factors affecting reproductive and productive performance of crossbred dairy cattle in the Sudan.

HARVEY, W.R.: (1994) M.V.Sc. Thesis, University of Khartoum-Sudan

HAILE-MARIAM, M.; BANJAW, K.; GEBRE-MESKEL, T.; KETEMA, H.:

Productivity of Boran cattle and their Friesian crosses at Abernossa Ranch, Rift Valley of Ethiopia. I. Reproductive performance and pre-weaning mortality. Trop. Anim. Health Prod. 25 (1993), 239-248

FACO, O.; LOBO BRAGA, R.N.; FILHO, M.; RAIMUNDO:

Age at first calving and calving interval of five Holstein x Gir genetic groups in Brazil. R. Bras. Zootec. 34 (2005) 6, 1920-1926

GOSHU, G.:

Breeding efficiency, lifetime lactation and calving performance of Friesian-Borancrossbred cows at ISHAG, I.A.: Cheffa farm, Ethiopia. Livestock research for Rural Development 17 (2005) 7

Impact of genetic and non-genetic factors on productive and productive traits of crossbred cows raised under Sudan conditions. (2000) M.V.Sc. Thesis, University of Khartoum- Sudan

MADALENA, F.E.:

Crossbreeding effects in tropical dairy cattle Proceedings of the ${ }^{\text {th }}$ World Congress on Genetics Applied to Livestock Production, Edinburgh, Scotland, July 1990, Vol. XIV: 310-319

MADALENA, F.E.:

Hybrid F1 Bos Taurus x Bos indicus dairy cattle production in the state of Minas Gerais, Brazil. Proceedings of the $6^{\text {th }}$ World Congress on Genetics Applied to Livestock Production, Armidale, Australia, 27 (1998), 199-202.

McDOWELL, R.E.:

Crossbreeding in tropical areas with emphasis on milk, health and fitness. J. Dairy Sci. 68 (1985), 2418-2435

MUSA, L.M-A.; AHMED, M-K.A.; PETERS, K.J.; ZUMBACH, B.; GUBARTALLA, K.E.A.:

The reproductive and milk performance merit of Butana cattle in Sudan. Arch. Tierz., Dummerstorf 48 (2005) 5, 445-459

OSMAN, A.H.; RUSSELL, W.S.: 
Comparative performance of different grades of European Zebu cross-bred cattle at Ghurashi Farm. Sudan Trop. Agric. Trinidad 51 (1974), 549-558

REGE, J.E.O.:

Utilization of exotic germplasm for milk production in the tropics. Proceedings of the 6th World Congress on Genetics Applied to Livestock Production. Armidale, Australia, 25 (1998), 193-200

SYRSTAD, O:

Dairy cattle crossbreeding in the tropics: performance of secondary crossbred populations. Livest. Prod. Sci. 25 (1989), 97-106

SYRSTAD, O.:

Dairy cattle crossbreeding in the tropics: Choice of crossbreeding strategy. Trop. Anim. Health and Prod. 28 (1996), 223-229

TEODORO, R.L.; MADALENA, F.E.:

Dairy Production by crosses of Holstein, Jersey, or Brown Swiss sires with Holstein-Friesian/Gir dams. Tropical Animal Health and Production 35 (2003), 105-115

VACCARO, L.; PÉREZ, A.; VACCARO, R.:

Productive performance of $\mathrm{F}_{1}$ compared with other 50\% European-zebu crossbred cows for dual purpose systems in the Venezuelan tropics. Livestock Research for Rural Development 11 (1999) 1

WOLLNY, C.B.A.; NAMWAZA, A.G.; MAKAMBA, T.S.W.; KUETTNER, K.:

Zum Stand der Rinderzucht in Malawi. Arch. Tierz., Dummerstorf 41 (1998) 2, 33 - 44

Received: 2006-09-18

Accepted: 2007-01-07

Corresponding Author

Prof. Dr. KURT J. PETERS

Department of Animal Breeding and Aquaculture

in the Tropics and Subtropics,

Faculty of Agriculture and Horticulture,

Humboldt University-Berlin, Philippstr. 13, House No. 9

10115 BERLIN, GERMANY

E-Mail: k.peters@agrar.hu-berlin.de 